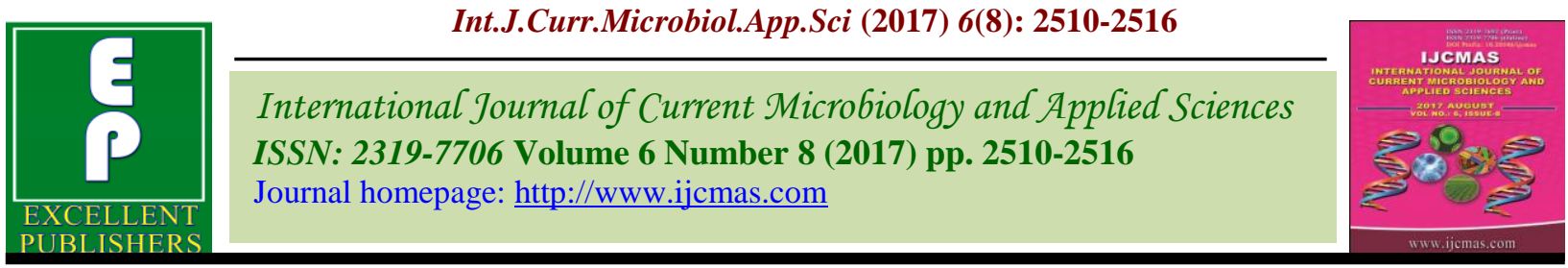

Original Research Article

https://doi.org/10.20546/ijcmas.2017.608.297

\title{
Effect of Integrated Use of Fertilizer and Manures on Growth, Yield and Quality of Pearl Millet
}

\author{
Ramdev Togas", L.R. Yadav, S.L. Choudhary and G.V. Shisuvinahalli \\ Department of Agronomy, S.K.N. College of Agriculture, Jobner, Jaipur, Rajasthan, India \\ *Corresponding author
}

\author{
A B S T R A C T
}

\begin{tabular}{l} 
Ke y w or d s \\
Manures, \\
Fertilizers, \\
Plant height, \\
Tillers, Grains. \\
\hline Article Info \\
\hline $\begin{array}{l}\text { Accepted: } \\
21 \text { June } 2017 \\
\text { Available Online: } \\
\text { 10 August } 2017\end{array}$ \\
\hline
\end{tabular}

A field experiment was conducted at Agronomy farm, of S.K.N. College of Agriculture, Jobner (Rajasthan) during kharif 2015 on loamy sand soil, which consisted eight treatments of fertilizers/manures (Control, RDF (60:30:0), FYM @ 12 t/ha, FYM @ 6 t/ha +1/2RDF, vermicompost @ 5 t/ha, Vermicompost @ 2.5 t/ha+1/2 RDF, Poultry Manure @ 4 t/ha, Poultry Manure @ 2 t/ha + 1/2 RDF) and two treatments of microbial inoculation (without inoculation and with Azotobacter) thereby making sixteen treatment combinations were tested in randomized block design with three replications. Recommended dose of fertilizer for pearlmillet was $60 \mathrm{~kg} \mathrm{~N}$ and $30 \mathrm{~kg} \mathrm{P}_{2} \mathrm{O}_{5} / \mathrm{ha}$. Results indicated that application of Vermicompost @ 2.5 t/ha +1/2 RDF, FYM @ 6 t/ha +1/2 RDF and Poultry Manure @ 2 t/ha $+1 / 2$ RDF remaining at par with each other and significantly increased plant height, dry matter accumulation, total number of tillers, chlorophyll content effective tillers, ear length, grains/ear, test weight, grain, stover and biological yield, protein content over control. Nitrogen and potassium content in grain were significantly increased due to application of poultry manure @ $2 \mathrm{t} / \mathrm{ha}+1 / 2 \mathrm{RDF}$. However phosphorus content in grain was significantly increased due to application of vermicompost @ $2.5 \mathrm{t} / \mathrm{ha}+1 / 2 \mathrm{RDF}$ and nitrogen, phosphorus and potassium content in stover and their uptake were significantly increased due to application of vermicompost @ $2.5 \mathrm{t} / \mathrm{ha}+1 / 2 \mathrm{RDF}$. Application of poultry manure @ 2 t/ha +1/2 RDF gave highest net returns of `34898/ha

\section{Introduction}

Pearlmillet [Pennisetum glaucum (L.) R. Br. emend Stuntz] is one of the important millet crop of hot and dry areas of arid and semi-arid climatic condition particularly of Rajasthan. It has been estimated that pearlmillet embodies a tremendous productivity potential particularly in areas having extreme environmental stress condition on account of drought. It is nutritionally better than many cereals as it is a good source of protein having higher digestibility (12.1\%), fats (5\%), carbohydrates $(69.4 \%)$ and minerals $(2.3 \%)$.
Increased use of fertilizers without organic recycling has not only aggravated multinutrient deficiencies in soil-plant-system but also detrimental to soil health and has created environmental pollution. Moreover, chemical fertilizers are becoming costlier in agriculture. Therefore, it is the right time to evaluate the feasibility and efficiency of organic sources not only for improving and building up soil fertility but also to increase the fertilizer use efficiency. Integration of chemical fertilizer with organic manures has been found quite promising not only in sustaining the soil 
health and productivity but also in stabilizing the crop production in comparison to the use of each component, separately (Nambiar and Abrol, 1992).

\section{Materials and Methods}

The field experiment was conducted at Agronomy farm of S.K.N. College of Agriculture, Jobner during Kharif season of the year 2015 with pearlmillet variety "Raj171 " which is a medium statured variety attaining a height of about $200 \mathrm{~cm}$ with good tillering capacity and suitable for normal as well as late sown conditions. The climate of this region in typically semi- arid, with extremes of temperatures during both the seasons.

During summers, the temperature may go as high as $48^{\circ} \mathrm{C}$ while in winter, it may fall as low as $-1.0^{\circ} \mathrm{C}$. The soil of the experimental field was loamy sand in texture and alkaline in reaction. It was poor in organic carbon, low in available nitrogen and phosphorus and medium in available potash.

The experiment consisted 16 treatment combinations involving eight treatments of fertilizers and manures [Control, RDF (60:30:0), FYM @ 12T/ha, FYM @6 t/ha + $1 / 2$ RDF, Vermicompost @ 5 t/ha, Vermicompost@2.5 t/ha + 1/2 RDF, Poultry Manure@ 4 t/ha, Poultry Manure @ 2 t/ha + $1 / 2 \mathrm{RDF}]$ and two treatments of microbial inoculation (Without inoculation, With Azotobacter).

The experiment was basically planned as rainfed but due to long dry spell at reproductive stage, one life saving irrigation was given on 09.09.2015.

The experimental area (net plot) was harvested separately from each plot on October 2, 2015 leaving two border rows on each side along the length of the plot and 0.5 $\mathrm{m}$ along the width on both sides. The harvested produce of each net plot was tied up in the bundles separately and tagged.

\section{Results and Discussion}

Data presented in table 1 showed that application of fertilizers and manures to pearlmillet had no significant effect on plant stand recorded at 20 DAS and at harvest. Thus it reveals that plant stand was almost uniform in all the treated plots.

\section{Growth attributes}

A perusal of data (Table 1) revealed that application of fertilizers and manures significantly enhanced the plant height, dry matter accumulation, total tillers per metre row length and chlorophyll content of pearlmillet over control.

The better growth in terms of plant height, dry matter accumulation total tillers per metre row length and chlorophyll content was recorded due to application of vermicompost @ $2.5 \mathrm{t} / \mathrm{ha}+1 / 2 \mathrm{RDF}$ than rest of the treatments. However, it remained at par with poultry manure @ $2 \mathrm{t} / \mathrm{ha}+1 / 2 \mathrm{RDF}$ and FYM @ 6 t/ha +1/2 RDF.

It is the established fact that vermicompost improves the physical and biological properties of soil including supply of almost all the essential plant nutrients for the growth and development of plants. Vermicompost provides secondary elements like $\mathrm{Ca}, \mathrm{Mg}$, and $\mathrm{S}$ and fairly high amounts of micronutrients to the plants.

It also increases CEC, water holding capacity and phosphate availability in the soil. Thus balanced nutrition due to release of macro and micro nutrients due to application of vermicompost, poultry manure and FYM 
under favourable environment might have helped in higher uptake of nutrients. This accelerated the growth of new tissues and development of new shoots that have ultimately increased the plant height, dry mater accumulation, chlorophyll content and total tillers per metre row length. The results of present investigation are in conformity with those of Thakral et al., (2000), Yadav and Beniwal (2004), Parihar et al., (2012) in pearlmillet and Patidar and Mali (2004) in sorghum.

\section{Yield attributes and yield}

A reference to the data presented in table 1 revealed that numbers of effective tillers per metre row length, grains per ear head, ear length, test weight, grain yield, stover yield, biological yield and harvest index were significantly increased by all the treatments of fertilizers/manures over control.

Yield attributes viz., number of effective tillers, number of grains per ear and test weight improved by application of vermicompost@2.5 t/ha + 1/2 RDF, poultry manure@2t/ha+1/2RDF and FYM @6t/ha $+1 / 2$ RDF as compared to other treatments.

This could mainly be associated with the increased growth of the crop in terms of plant height, dry matter accumulation and higher number of tillers recorded under these treatments due to greater availability of most of the macro and micro nutrients in appropriate amounts and balanced proportion that led to higher uptake of the nutrients.

The increased growth provided greater site for photosynthesis and diversion of photosynthates towards sink (ear and grain). The beneficial effect on yield attributes might also be due to the increased supply of all the essential nutrients by vermicompost, poultry manure and FYM that might have resulted in higher manufacture of food and its subsequent partitioning towards sink. The findings of present investigation are supported by Khan et al., (2000) in pearlmillet and Kumawat and Jat (2005) in barley.

Significantly higher grain yield was obtained by the application of vermicompost @2.5 t/ha $+1 / 2$ RDF as compared to other treatments except poultry manure @ 2 t/ha +1/2 RDF and FYM @ $6 \mathrm{t} / \mathrm{ha}+1 / 2 \mathrm{RDF}$. The higher values of yield attributes like effective tillers per metre row length, number of grains per ear head, ear head length and test weight coupled with the higher crop dry matter observed with these treatments might have been the most probable reason of higher grain and stover yield.

The increase in grain yield of pearlmillet with these treatments was also largely due to high harvest index that showed high partitioning of the plant assimilates towards the sink. Since, biological yield is a sum of grain and stover yields, the improvement in these parameters as discussed above also enhanced the biological yield significantly due to these treatments.

\section{Economics}

It is apparent from the data (Table 1) that treatment PM @ $2 \mathrm{t} / \mathrm{ha}+1 / 2 \mathrm{RDF}$ recorded highest net returns ( $34898 /$ ha) which was at par with FYM @ 6 t/ha + 1/2 RDF and gave significantly higher net returns over rest of the treatment.

Data presented in table 1 revealed that application of PM @ 2 t/ha + 1/2 RDF recorded the maximum $\mathrm{B}$ : $\mathrm{C}$ ratio (3.13) among all the treatments. It was at par with application of RDF. Whereas, the net returns per rupees investment provided by control, FYM@ 12 t/ha, FYM @6t/ha +1/2 RDF, VC @ 5 t/ha, VC @ 2.5 t/ha +1/2 RDF, and PM @ 4 t/ ha were Rs. 2.76, 2.39, 2.97, 1.27, 2.00 and 2.80 , respectively. 


\section{Int.J.Curr.Microbiol.App.Sci (2017) 6(8): 2510-2516}

Table.1 Effect of integrated use of fertilizer and manures on growth, yield attributes, yield and economics of pearl millet

\begin{tabular}{|c|c|c|c|c|c|c|c|c|c|c|c|c|c|c|c|}
\hline \multirow[b]{2}{*}{ Treatments } & \multirow[b]{2}{*}{$\begin{array}{l}\text { Plant } \\
\text { stand } \\
\text { per } \\
\text { m row }\end{array}$} & \multicolumn{4}{|c|}{ Growth characters } & \multicolumn{5}{|c|}{ Yield attributes } & \multicolumn{3}{|c|}{ Yield (kg/ha) } & \multicolumn{2}{|c|}{ Economics } \\
\hline & & $\begin{array}{l}\text { Plant } \\
\text { height } \\
(\mathrm{cm})\end{array}$ & $\begin{array}{l}\text { Dry } \\
\text { matter } \\
\text { accumul } \\
\text { ation }\end{array}$ & $\begin{array}{l}\text { Total } \\
\text { tillers } \\
\text { per } \\
\text { metre } \\
\text { row } \\
\text { length }\end{array}$ & $\begin{array}{l}\text { Chlorophyll } \\
\text { content }\end{array}$ & $\begin{array}{l}\text { No. Of } \\
\text { effective } \\
\text { tillers per } \\
\text { metre row } \\
\text { length }\end{array}$ & $\begin{array}{l}\text { Grain } \\
\text { per } \\
\text { ear } \\
\text { head }\end{array}$ & $\begin{array}{l}\text { Ear } \\
\text { length }\end{array}$ & $\begin{array}{l}\text { Test } \\
\text { weight } \\
\text { (gm) }\end{array}$ & $\begin{array}{l}\text { Harvest } \\
\text { Index } \\
(\%)\end{array}$ & $\begin{array}{l}\text { Grain } \\
\text { yield }\end{array}$ & $\begin{array}{l}\text { Stover } \\
\text { yield }\end{array}$ & $\begin{array}{l}\text { Biological } \\
\text { yield }\end{array}$ & $\begin{array}{l}\text { Net } \\
\text { return } \\
\text { (Rs./ha) }\end{array}$ & $\begin{array}{l}\mathrm{B}: \mathrm{C} \\
\text { ratio }\end{array}$ \\
\hline \multicolumn{16}{|l|}{$\begin{array}{l}\text { Organic } \\
\text { manures/ } \\
\text { Fertilizers }\end{array}$} \\
\hline Control & 7.5 & 165.8 & 236.4 & 19.1 & 2.60 & 18.0 & 1080 & 23.9 & 6.10 & 25.02 & 1212 & 3630 & 4842 & 23844 & 2.76 \\
\hline $\begin{array}{l}\text { RDF } \\
(60: 30: 0)\end{array}$ & 7.4 & 178.5 & 265.9 & 21.6 & 2.70 & 20.1 & 1261 & 26.9 & 6.92 & 25.86 & 1585 & 4542 & 6127 & 31891 & 3.03 \\
\hline $\begin{array}{l}\text { FYM @ } 12 \\
\text { t/ha }\end{array}$ & 7.7 & 178.6 & 276.3 & 21.9 & 2.73 & 20.9 & 1252 & 26.1 & 6.30 & 25.56 & 1539 & 4480 & 6019 & 27146 & 2.39 \\
\hline $\begin{array}{l}\text { FYM @ } 6 \\
\text { t/ha + 1/2 } \\
\text { RDF }\end{array}$ & 7.9 & 195.8 & 310.5 & 25.0 & 2.89 & 23.9 & 1366 & 29.6 & 7.41 & 26.17 & 1755 & 4950 & 6705 & 34633 & 2.97 \\
\hline $\begin{array}{lll}\mathrm{VC} & @ 5 \\
\mathrm{t} / \mathrm{ha} & & \\
\end{array}$ & 7.8 & 185.3 & 293.9 & 25.1 & 2.80 & 22.6 & 1250 & 27.0 & 6.40 & 26.01 & 1635 & 4650 & 6285 & 10400 & 1.27 \\
\hline $\begin{array}{l}\text { VC @ } 2.5 \\
\text { t/ha + 1/2 } \\
\text { RDF }\end{array}$ & 7.9 & 198.5 & 320.5 & 27.0 & 2.93 & 25.1 & 1369 & 30.6 & 7.59 & 26.32 & 1830 & 5120 & 6950 & 27117 & 2.00 \\
\hline $\begin{array}{l}\text { P.M. @ } 4 \\
\text { t/ha }\end{array}$ & 7.9 & 184.1 & 290.1 & 23.7 & 2.78 & 22.0 & 1251 & 27.9 & 6.30 & 25.94 & 1601 & 4570 & 6171 & 30883 & 2.80 \\
\hline $\begin{array}{llr}\text { P.M. } & \text { @ } \\
\text { t/ha+ } & & 1 / 2 \\
\text { RDF } & & \end{array}$ & 8.0 & 196.1 & 318.1 & 25.9 & 2.91 & 23.3 & 1348 & 29.1 & 7.42 & 26.12 & 1721 & 4867 & 6588 & 34898 & 3.13 \\
\hline $\mathrm{SEm} \pm$ & 0.23 & 6.2 & 9.0 & 0.7 & 0.07 & 0.7 & 33 & 0.8 & 0.19 & 0.76 & 52 & 192 & 261 & 981 & 0.08 \\
\hline $\begin{array}{l}\mathrm{CD} \\
(\mathrm{P}=0.05)\end{array}$ & NS & 17.9 & 26.0 & 2.0 & 0.20 & 2.0 & 95 & 2.4 & 0.57 & NS & 151 & 553 & 754 & 2833 & 0.23 \\
\hline
\end{tabular}


Int.J.Curr.Microbiol.App.Sci (2017) 6(8): 2510-2516

Table.2 Effect of integrated use of fertilizer and manures on contents and uptake of nutrients and quality parameters of pearlmillet

\begin{tabular}{|c|c|c|c|c|c|c|c|c|c|c|}
\hline \multirow[t]{3}{*}{ Treatments } & \multicolumn{6}{|c|}{ Nutrient content } & \multicolumn{3}{|c|}{ Nutrient uptake whole crop } & \multirow{3}{*}{$\begin{array}{c}\text { Kernels Quality } \\
\text { Protein } \\
(\%)\end{array}$} \\
\hline & \multicolumn{2}{|l|}{$\mathrm{N}(\%)$} & \multicolumn{2}{|l|}{$\mathrm{P}(\%)$} & \multicolumn{2}{|l|}{$\mathrm{K}(\%)$} & \multirow{2}{*}{$\begin{array}{c}\mathrm{N} \\
(\mathrm{kg} / \mathrm{ha})\end{array}$} & \multirow{2}{*}{$\begin{array}{c}\mathrm{P} \\
(\mathrm{kg} / \mathrm{ha})\end{array}$} & \multirow{2}{*}{$\begin{array}{c}\mathrm{K} \\
(\mathrm{kg} / \mathrm{ha})\end{array}$} & \\
\hline & Kernel & Haulm & Kernel & Haulm & Kernel & Haulm & & & & \\
\hline \multicolumn{11}{|c|}{$\begin{array}{l}\text { Organic manures/ } \\
\text { Fertilizers }\end{array}$} \\
\hline Control & 1.50 & 0.41 & 0.251 & 0.111 & 0.510 & 1.760 & 33.11 & 7.09 & 70.14 & 9.38 \\
\hline RDF (60:30:0) & 1.67 & 0.48 & 0.273 & 0.131 & 0.550 & 1.860 & 48.35 & 10.26 & 93.29 & 10.44 \\
\hline FYM@12t/ha & 1.61 & 0.47 & 0.265 & 0.127 & 0.570 & 1.880 & 45.90 & 9.78 & 93.09 & 10.06 \\
\hline \multicolumn{11}{|c|}{ FYM@6t/ha+1/2 } \\
\hline RDF & 1.68 & 0.49 & 0.273 & 0.132 & 0.575 & 1.905 & 53.82 & 11.34 & 104.49 & 10.50 \\
\hline VC@ @ t/ha & 1.79 & 0.51 & 0.278 & 0.138 & 0.582 & 1.960 & 53.06 & 10.98 & 100.75 & 11.19 \\
\hline \multicolumn{11}{|c|}{ VC @ 2.5 t/ha + 1/2 } \\
\hline RDF & 1.81 & 0.55 & 0.279 & 0.143 & 0.581 & 2.010 & 61.38 & 12.44 & 113.65 & 11.31 \\
\hline P.M. @ 4 t/ha & 1.75 & 0.48 & 0.276 & 0.135 & 0.580 & 1.930 & 50.03 & 10.60 & 97.58 & 10.94 \\
\hline \multicolumn{11}{|c|}{ P.M. @ 2 t/ha+ 1/2 } \\
\hline RDF & 1.84 & 0.54 & 0.276 & 0.138 & 0.589 & 1.990 & 58.04 & 11.48 & 107.09 & 11.50 \\
\hline $\mathrm{SEm} \pm$ & 0.04 & 0.02 & 0.007 & 0.005 & 0.016 & 0.053 & 2.25 & 0.53 & 3.60 & 0.39 \\
\hline $\mathrm{CD}(\mathrm{P}=0.05)$ & 0.13 & 0.05 & 0.020 & 0.013 & 0.046 & 0.153 & 6.51 & 1.54 & 10.40 & 1.14 \\
\hline
\end{tabular}




\section{Nutrient concentration, uptake and quality}

A significant increase in concentration of nitrogen, phosphorus and potassium in grain and stover of pearlmillet was observed due to application of vermicompost @ $2.5 \mathrm{t} / \mathrm{ha}$ and poultry manure @ $2 \mathrm{t} / \mathrm{ha}+1 / 2 \mathrm{RDF}$ (Table 2). The combined application of fertilizers/ manures significantly increased the concentration (nitrogen, phosphorus and potassium) in grain and stover. It can chiefly be associated with the better growth of the crop due to favourable nutritional environment mainly for supply of most of the macro and micro nutrients in balanced and available form throughout the growing period of the crop and in adequate amounts.

Since, the uptake of nutrients in grain and stover is a function of their concentration and yield, the increase in grain and stover yield coupled with increased nutrient concentration also resulted in higher total uptake of nitrogen, phosphorus and potassium with the application of vermicompost @ 2.5 t/ha $+1 / 2$ RDF and poultry manure @ 2 t/ha $+1 / 2 \mathrm{RDF}$ (Table 2). Use of organic manures viz., vermicompost, poultry manure and FYM has also been known to help in reducing the soil $\mathrm{pH}$ to some extent by producing organic acids while their decomposition that may also be the reason of greater availability and mobility of nutrients mainly of micronutrients. This could have also helped in additional uptake of the nutrients by plants.

The protein content in grain (Table 2) is in fact a manifestation of nitrogen concentration in grain. The increased concentration of nitrogen in grain directly resulted in high protein content recorded with application of Poultry manure @ 2 t/ha $+1 / 2$ RDF in comparison to rest of the treatments. The findings of the present investigation are in agreement with those of Kathuria et al., (2003) in pearlmillet, Nehra et al., (2005) and
Singh and Singh (2005) in wheat and Kumawat and Jat (2005) in barley and Choudhary and Gautam (2007) in pearlmillet.

\section{References}

Choudhari, R.S. and Gautam, R.C 2007. Effect of nutrient-management practices on growth and yield of pearlmillet (Pennisetum glaucum). Indian Journal of Agronomy 52 (1): 64-66.

Katuria, M.K., Singh, Harbir, Singh, K.P. and Kadian, V.S. 2003. Effect of integrated nutrient management on fodder and nutrient uptake by Kharif fodder under cereal fodder-wheat cropping system. Haryana Journal of Agronomy 19 (1): 83-86.

Khan, H., Jain, P.C. and Trivedi, S.K. 2000. Nutrient management in pearlmillet (Pennisetum glaucum L.) under rainfed condition. Indian Journal of Agronomy 45 (4): 728-731.

Kumawat, P.D. and Jat, N.L. 2005. Effect of organic manure and nitrogen fertilization on productivity of barley. Indian Journal of Agronomy 50 (3): 200-202.

Nambiar, K.K. M. and Abrol, I.P. 1989. Long term fertilizer experiments in India an over view. Fertilizer News 34: 11-20

Nehra, A.S., Hooda, I.S. and Singh, K.P. 2001. Effect of integrated nutrient management on growth and yield of wheat. Indian Journal of Agronomy 46 (1): 112-117.

Parihar, C.M., Rana, K. S. Jat, M. L., Jat, S. L., Parihar, M. D., Kantwa, S.R., Singh D.K. and Sharma, S. 2012. Carbon footprint and economic sustainability of pearlmillet-mustard system under different tillage and nutrient management practices in moisture stress conditions. African Journal of Microbiology Research 6 (23), pp. 5052-5061. 
Patidar, M. and Mali, A.L. 2004. Effect of Farm yard manure, fertility levels and biofertilizers on growth, yield and quality of sorghum. Indian Journal of Agronomy 49 (2): 117-120.

Singh, J. and Singh, K.P. 2005. Effect of organic manures and herbicides on yield and yield attributing characters of wheat. Indian Journal of Agronomy 50 (4): 289-291.
Thakral, S.K., Kumar, S. and Singh, S. 2000. Response of pearlmillet to organic manures and fertilizers under saline soil conditions Haryana Journal of Agronomy 16: 76-78.

Yadav, N.D. and Beniwal, R.K. 2003. Response of pearlmillet to N and FYM under rainfed condition. Arid zone Research Association of India 5: 276279.

\section{How to cite this article:}

Ramdev Togas, L.R. Yadav, S.L. Choudhary and Shisuvinahalli, G.V. 2017. Effect of Integrated Use of Fertilizer and Manures on Growth, Yield and Quality of Pearl millet. Int.J.Curr.Microbiol.App.Sci. 6(8): 2510-2516. doi: https://doi.org/10.20546/ijcmas.2017.608.297 